\title{
SAMHÄLLSPÅFÖLJDER I DET FINSKA PÅFÖLJDSSYSTEMET
}

\author{
AV DIREKTÖR, DOCENT JUR.DR. TAPIO LAPPI-SEPPÄLÄ
}

Suspended sentences and parole supervision are traditional community sanctions and measures. In 1950, 30\% of sentences of imprisonment were suspended. The corresponding rate in 1999 was 62\%. The suspended sentence has been one of the key tools through which Finland has succeeded in lowering its prison population during recent decades. New alternatives, introduced during the 1990s, are community service and juvenile punishment.

An experiment with community service began in Finland in 1991. In 1997, community service became a permanent part of the system of sanctions. It can be used only in cases where the defendant would otherwise have received an unconditional sentence of up to eight months of imprisonment. The length of community service is at least twenty and at most 200 hours. One day of imprisonment corresponds to one hour of community service. Within a short period of time the number of community service orders imposed each year reached the level of 3,0004,000. At the same time, the number of prison sentences fell significantly. Community service has clearly been able to function as a real alternative to imprisonment. In 2000, the average daily number of offenders serving a community service order was about 1,200, while the corresponding number of prisoners was around 3,000. Failure to complete the terms of community service has varied between 11-15\%.

In 1996, an experiment with a new sanction for young persons age 1517 was introduced in five jurisdictions. The primary aim of juvenile punishment was to avoid the repeated use of suspended sentences among high-risk adolescents. This sanction consists of youth service (10-60 hours) and supervision (4 months - 1 year). In terms of severity, juvenile punishment falls somewhere between a fine and a prison sentence. When choosing between suspended sentence and juvenile punishment, the latter should be chosen if "juvenile punishment is deemed justified in order to prevent new offences and promote the social adjustment of the young offender". Successful completion of the program has been much lower than that shown for community service. This is no surprise given the greater overall tendency for misbehaviour among youths as opposed to adults. As a rule, the interruption of a sentence is regularly associated with serious drug or alcohol problems. Experiences with both community service orders and juvenile punishments confirm that the Finnish sanctioning system should pay additional attention to problems resulting from drug and alcohol abuse.*

\footnotetext{
* Title in English: Community Sanctions in Finland. Original in Swedish.
} 


\section{Allmänt}

Fängelse, samhällstjänst, böter och ordningsbot är allmänna straff enligt strafflagen i Finland (SL 2:1). Fängelse kan dömas antingen villkorligt eller ovillkorligt. I en del av landet har man härutöver i bruk en försöksverksamhet med ungdomsstraff. Domseftergift räknas också ofta som ett av straffen.

Termen samhällsstraff (samhällspåföljd) i sig nämns inte i lagen och termen har inte heller närmare definierats i rättslitteraturen. Samhällsstraff syftar på en strävan att verkställa straffen inom samfundet, dvs. utan att avstänga den dömda från samhället. I denna betydelse kan alla alternativ (s.k. öppna påföljder) till anstaltstraff inbegripas, även domseftergift, böter och villkorligt fängelse. Med termen avses dock vanligen enbart sådana påföljder, där verkställigheten är förknippad med kriminalvårdsåtgärder av något slag (och som på ett eller annat sätt syftar till social reintegration, se närmare t.ex. Kalmthouth 2000 s.123). Detta skulle avgränsa påföljder av ren varningstyp från samhällspåföljderna. Det finska påföljdssystemet känner, på detta sätt uppfattat, två nya samhällsstraff: samhällstjänst och ungdomsstraff. I systemet har sedan gammalt ingått de traditionella samhällspåföljderna villkorligt fängelse, inklusive övervakning för unga förbrytare, samt övervakning av villkorligt frigivna. Påföljderna kan även indelas enligt målgrupp. Ungdomsstraff och övervakning vid villkorligt straff gäller enbart unga lagöverträdare. Användningen av samhällstjänst och övervakning av villkorligt frigivna är inte bundna till åldern.

Samhällsstraffens andel i de olika systemen kan granskas på basis av såväl domsstatistik som dagliga verkställighetsuppgifter. I Finland utdöms för tillfället årligen ca 3500 samhällstjänststraff, knappt hundra ungdomsstraff och drygt 12000 villkorliga fängelsestraff (av dessa döms de unga till drygt 2000 straff inklusive övervakning). Knappt 1000 gärningsmän meddelas domseftergift. Antalet utdömda böter är ca 35000 och de ovillkorliga fängelsestraffens antal är knappa 8000. Av de i domstolarna årligen utdömda ca 60000 straffen är således andelen samhällspåföljder knappt 10\%. Därtill friges årligen knappa 4000 fångar villkorligt, varav ungefär en fjärdedel döms till övervakning. Enligt denna beräkningsgrund utdöms årligen ca 7000 samhällspåföljder (se närmare Rikollisuustilanne 1999).

Antalet straff som dagligen är i verkställighet framgår av tabell 1. Av de villkorliga straffen har medräknats enbart de straff där den dömde förordnats övervakning. 
Tabell 1. Straff under verkställighet 1.5.2000.

\begin{tabular}{|l|r|}
\hline Samhällspåföljder & 3960 \\
\hline Ungdomsstraff & 49 \\
\hline Övervakning vid villkorligt fängelse & 1485 \\
\hline Samhällstjänst & 1194 \\
\hline Övervakning av villkorligt frigivna & 1232 \\
\hline Fångar (alla fånggrupper) & 2917 \\
\hline
\end{tabular}

Källa: Kommittébetänkande 2001:2 samt fångvårdsavdelningen.

Ca 4000 samhällsstraff (definierade på detta sätt) är dagligen under verkställighet. Det dagliga fångantalet i sin tur är knappt 3/4 av antalet samhällspåföljder som förutsätter kriminalvårdsåtgärder.

Största delen av verkställighetsuppgifterna inom den öppna kriminalvården har i Finland anförtrotts den offentligrättsliga Kriminalvårdsföreningen (KVF). KVF har således hand om verkställigheten av samhällstjänst samt övervakningen av villkorligt frigivna och övervakningen av villkorligt straffade unga. I den senare gruppen har KVF hjälp av privata övervakare som gör frivilligarbete. KVF har i samarbete med socialmyndigheterna även hand om verkställigheten av det nya ungdomsstraffet. KVF har utöver nämnda uppgifter ansvaret för frigivna fångars eftervård och därtill anknutna stödåtgärder av olika slag (se närmare Vogt-Airaksinen 2000).

Den offentligrättsliga Kriminalvårdsföreningens roll som de statliga straffens halvofficiella verkställare har dryftats i flera på 1980- och 1990-talet tillsatta arbetsgrupper. Den revision av de grundläggande fri- och rättigheterna i Regeringsformen som förverkligades år 1998 samt den mer omfattande användningen av samhällspåföljder ledde sedermera till att man även i vidare bemärkelse måste bedöma straffverkställighetens organisatoriska lösningar. Som ett resultat av denna bedömning gjordes år 2001 en revidering av justitieministeriets organisation. Revideringen innebar att man överflyttade samhällspåföljdernas verkställighetsuppgifter från Kriminalvårdsföreningen till den nya kriminalpolitiska avdelningen som inrättats vid justitieministeriet och till brottspåföljdsverket som lyder under nämnda avdelning. Kriminalvårdsföreningen, vars verksamhet har inskränkts, skall enligt planerna i fortsättningen i stiftelseform erbjuda sociala och andra typer av stödjande tjänster.

Lagstiftningen som gäller de traditionella samhällspåföljderna (villkorligt straff och villkorlig frihet) har en längre tid varit oförändrad. Den nyklassiska påföljdspolitiken, som styrt revideringen av påföljdssystemet sedan 1970-talet, hade över huvud taget inget nämnvärt intresse för utvecklandet av samhällspåföljder som innefattar socialiserande eller rehabiliterande element, låt vara att t.o.m. flera betänkanden om olika (kontrollinriktade) övervakningspåföljder 
publicerades. I detta avseende innebar de nya samhällspåföljder som togs i bruk på 1990-talet onekligen en partiell ändring av den tidigare linjen. En strävan att minska användningen av anstaltstraff (om de härvid uppnådda resultaten, se närmare Lappi-Seppälä 2000a) följer fortfarande de tidigare linjedragningarna. En förändring med avseende på det tidigare framgår framför allt av de nya påföljdernas innehåll, användningsförutsättningar och mål. Samhällstjänsten och ungdomsstraffet har båda på sätt och vis fört en tredje dimension till sanktionssträngheten och till påföljdernas nyklassiska "stegmodell" som bygger på straffets stränghet. Fråga är inte längre enbart om ett rättvist förhållande mellan brottets förkastlighet och straffets stränghet, utan fråga är allt oftare också om påföljdens lämplighet för den dömda, samt om en möjlighet att främja den dömdas livskontroll och hans förutsättningar att klara sig socialt (om kriminalpolitisk idéutveckling i Norden se även Lahti 2000 med hänvisningar).

Det är skäl att göra vissa preciseringar: Trots att det enligt det traditionella straffteoretiska begreppskomplexet eventuellt är fråga om en partiell återgång till de specialpreventiva metoderna, skiljer samhällspåföljderna sig beträffande innehåll, metod och användningsprincip från förbättringsperiodens "vårdåtgärder". Samhällspåföljderna behandlar inte de dömda som passiva objekt för tvångsåtgärder, utan betonar de egna valens betydelse och ansvaret för de egna besluten. Ett tecken på detta är t.ex. sättet att förena dessa påföljder med avtalsdiskussioner och förhandlingar om påföljdens innehåll med den dömda, samt den gärningsmannen givna friheten och ansvaret att själv besluta om utförandet av själva påföljden. Man har också försökt avvärja risken för dold bestraffning, under beteckningen vård, $\mathrm{i}$ och med att de socialiserande och rehabiliterande målsättningarna inte berättigar användningen av en påföljd som är strängare till innehållet eller hårdare ingriper i den dömdas liv, jämfört med en situation där man skulle ty sig till gamla alternativ som redan är i bruk. Strävan att ta den dömdas närsamfund med i verkställigheten av påföljderna, är å sin sida även tecken på ett nytt sätt att framhäva vikten av samhällets och individens sociala växelverkan och relationer.

I samhällspåföljderna betonas således delvis samma (kommunitaristiska) värden och mål som styrt de reformkrav som olika rörelser inom medlingen har framfört (se Duff 2001 s.75 ff). Samhällspåföljdernas och medlingssystemens samtidiga genombrott torde inte heller annars bara vara en tidsmässig tillfällighet. Det på 1980-talet i Finland ibruktagna medlingsförfarandet har bibehållit sin inofficiella alternativa karaktär utan att förfarandet har integrerats som en del av det straffrättsliga påföljdssystemet. Medling nämns dock i lagen som en av grunderna med stöd av vilka gärningsmannen kan meddelas åtals- eller domseftergift. Det är även för den skull motiverat att nedan till granskningen av samhällsstraffen foga en kort redogörelse över medling av brott och därav erhållna erfarenheter. 


\section{Villkorligt straff}

\section{Allmänt}

Det villkorliga straffet togs i bruk i Finland år 1918. Påföljdens syften och användningsprinciper följde den tidens internationella specialpreventiva strömningar. Lagstiftningen reformerades år 1976. I och med reformen utvidgades det villkorliga straffets tillämpningsområde. Samtidigt kopplades användningen av det villkorliga straffet från specialprevention till allmänprevention och till det som "upprätthållandet av den allmänna laglydnaden" vid respektive tidpunkt förmodades förutsätta. Lagen om villkorligt straff från år 1976 var en stilren nyklassisk straffrättsreform. Sedermera har lagstiftningen om villkorligt straff förblivit rätt oförändrad. I skrivande stund behandlas i riksdagen ett förslag om revidering av bestämmelserna om villkorligt straff (RP 177/2000). Förslaget preciserar det villkorliga straffets användningsförutsättningar, men påföljdens ställning i straffsystemet skulle till sina centrala delar förbli oförändrad.

Enligt lagen kan ett fängelsestraff i högst två år förklaras villkorligt, om inte hänsyn till den allmänna laglydnaden kräver att straffet ådöms ovillkorligt (VillkstraffL 1 §). I rättslitteraturen och -praxisen har man tolkat detta krav att det i sista hand hänvisar till sådana omständigheter med stöd av vilka man fastställer det klandervärda i gärningsmannens förfarande. Dylika omständigheter är framför allt brottets allvarlighet och gärningsmannens återfall i brott. Därtill påverkande skäl är gärningsmannens unga ålder. Efter den år 1989 gjorda lagändringen får en person som begått ett brott innan han fyllt 18 år inte dömas till ett ovillkorligt fängelsestraff "om det inte finns vägande skäl" (VillkstraffL $1.2 \S, 992 / 1989)$. En fjärde betydande grund vid valet av villkorligt fängelsestraff som straffart omfattar olika skälighets- och ändamålsenlighetssynpunkter (t.ex. gärningsmannens höga ålder, svaga hälsa, familjeförhållanden samt sociala svårigheter) .

Kravet på "hänsyn till den allmänna laglydnaden" är mycket oprecist och lämnar allför stort rum för tolkning. Det föreslås därför, att de ovannämnda kriterierna skulle inskrivas direkt i lagen (RP 177/2000 samt strafflagsprojekts förslag till straffrättens allmänna läror, utgiven år 2000).

Utöver fängelsestraff kan även ett bötesstraff förklaras villkorligt "av särskilda skäl”. Den sistnämnda bestämmelsen har i praktiken förblivit en död bokstav. Villkorligt straff innebär i Finland bara villkorligt fängelse.

Ifall ett villkorligt fängelsestraff ensamt för sig anses vara en otillräcklig påföljd, kan lagbrytaren utöver det villkorliga fängelsestraffet dömas till ovillkorligt bötesstraff (s.k. böter som tilläggsstraff). I förslaget (RP 177/2000) föreslås att området för tilläggspåföljder utvidgas så, att man som en skärpning till ett villkorligt fängelsestraff på mer än ett år skulle kunna utdöma samhällstjänst mellan 20 och 90 timmar. 


\section{Innebörden av villkorligt straff}

Det utdömda straffet är villkorligt under den tidsperiod som domstolen fastställt (prövotid). Prövotiden är till sin längd minst ett år och högst tre år. Ett villkorligt straff kan verkställas om den dömde under prövotiden begått ett nytt brott för vilket ett fängelsestraff enligt domstolens prövning följer. Misskötsamhet ensamt är således inte en tillräcklig grund för att verkställa ett villkorligt straff. En ytterligare förutsättning är, att åtal för det nya brottet väckts senast inom ett år från prövotidens utgång.

I praktiken blir förlusten av den suspensiva fördelen aktuell först när påföljden för det nya brottet är ovillkorligt fängelse. Även i dylikt fall bedöms behovet av förlusten av den suspensiva fördelen alltid skilt för sig. Omständigheter som skall tas i beaktande vid prövningen är bl.a. de tidigare villkorliga straffens antal, längden av det nya utdömda straffet samt även hur långt prövotiden framskridit.

Ett för unga personer (15-20 år när brottet begåtts) utdömt villkorligt straff kan även förenas med övervakning. Dömande till övervakning utgör huvudregeln och fyra av fem villkorligt straffade unga personer ställs under övervakning. Man kan avstå från övervakning, om rätten anser att den dömde antas "låta sig rättas också utan övervakning". Det föreslås att de redan från 1940-talet härstammande ålderdomliga bestämmelserna skall revideras så, att domstolen alltid skilt för sig skall bestämma när en ung person skall ställas under övervakning. Det skulle vara möjligt att döma till övervakning ifall "detta skall anses motiverat för att främja gärningsmannens möjligheter att anpassa sig i samhället och för att förhindra återfall i brott” (RP 177/2000).

Övervakningen består i huvudsak av regelbundna träffar med övervakaren. I vissa fall används olika gruppverksamhetsprogram. Övervakningen kan upphävas efter sex månader, ifall en fortsättning av den inte är av nöden. Övervakningen har skötts av kriminalvårdsföreningens egna anställda eller av frivilliga privata övervakare som förordnats till uppgiften.

\section{Numerära uppgifter}

Fängelsestraffets villkorlighet och ovillkorlighet under åren 1950-1999 framgår av följande tabell.

Tabell 2. Bruket av villkorligt straff 1950-1999

\begin{tabular}{|l|l|l|l|}
\hline & Ovillkorlig & Villkorlig & Fängelse i alt \\
\hline$\AA ̊ r$ & $\%$ & $\%$ & N \\
\hline 1950 & 70,5 & 29,5 & 9526 \\
\hline 1960 & 65,2 & 34,8 & 10586 \\
\hline 1970 & 66,2 & 33,8 & 15427 \\
\hline 1980 & 41,5 & 58,5 & 24882 \\
\hline 1990 & 40,1 & 59,9 & 29084 \\
\hline 1999 & $37,9^{*}$ & 62,1 & 20128 \\
\hline
\end{tabular}

*Ex] 
År 1950 förklarades 30\% av fängelsestraffen villkorligt, medan motsvarande antal var $62 \%$ år 1999. Det villkorliga fängelsestraffets användning ökade betydligt i synnerhet på 1970-talet. Bakom denna utveckling låg framför allt en omvärdering av rattfylleristraffen. Det villkorliga straffet är ett av de centrala medlen genom vilka Finland har lyckats sänka antalet fångar under de senaste årtiondena (se närmare Lappi-Seppälä 2000a). På 1980- och 1990-talet har det villkorliga och ovillkorliga straffets användningsandelar förblivit rätt oförändrade.

Tabell 3. Villkorliga straff vid några brottstyper 1999.

\begin{tabular}{|l|c|c|c|}
\hline & $\begin{array}{c}\text { Ovillkorliga* } \\
\text { N }\end{array}$ & $\begin{array}{c}\text { Villkorliga } \\
\text { N }\end{array}$ & $\begin{array}{c}\text { Andel villkorliga } \\
\text { fängelsestraff (\%) }\end{array}$ \\
\hline Rattfylleri & 3713 & 6829 & 64,8 \\
\hline Misshandel & 826 & 1045 & 55,8 \\
\hline Grov misshandel & 328 & 237 & 41,9 \\
\hline Stöld & 1764 & 1022 & 36,7 \\
\hline Skattebrott & 61 & 207 & 77,5 \\
\hline Konkursbrott & 20 & 94 & 82,5 \\
\hline Alla brott & 11324 & 12543 & 52,6 \\
\hline
\end{tabular}

*) Inklusive samhällstjänst

Andelen villkorliga straff varierar mellan de olika brottstyperna. Av de fängelsestraff som döms för stöld förklaras en tredjedel villkorliga. Vid ekonomiska brott stiger de villkorliga straffens andel till 70-80\%. Skillnaden förklaras framför allt av återfall i brott. I brottsgrupper där de dömda ofta har tidigare domar, är de villkorliga straffens andel av fängelsestraffen lägre.

I diskussionerna angående det villkorliga straffet har man ofta oroat sig för hur samma brottslingar (ofta unga personer) kan dömas till ett flertal villkorliga straff. Mer omfattande anhopning torde dock vara mindre vanlig än man förmodat. En utredning visar att endast 16\%, av alla personer som år 1992 för första gången dömdes till ett villkorligt straff, under de tre därpå följande åren dömdes till ett nytt villkorligt straff, och detta skedde i regel endast en gång. Under samma tid var andelen fler än två gånger på nytt dömda endast $2 \%$ av de dömda. Anhopningen var i de ungas grupp klart vanligare än för övriga grupper, men anhopningen var inte heller i detta fall den allmänna regeln. Av de unga som dömts till villkorligt straff döms dryga hälften till ett nytt villkorligt straff. Men av alla på nytt dömda unga döms tre fjärdedelar till endast ett eller två nya villkorliga straff. Av de till villkorligt straff dömda unga under 18 år tillhör $4 \%$ den problemgrupp, där under de följande åren minst fem nya villkorliga fängelsestraff utdömts, och $10 \%$ hör till en grupp, där högst fyra nya villkorliga straff 
utdömts (se Rikollisuustilanne 1999). För dessa unga har man söktefter andra påföljdsalternativ. Försöksverksamheten med ungdomsstraff är ett sådant alternativ (se nedan avsnitt IV).

\section{Samhällstjänst}

\section{Ibruktagandet av samhällstjänst}

En försöksverksamhet med samhällstjänst inleddes i Finland år 1991, till en början i en del av landet och senare som riksomfattande. År 1997 blev samhällstjänsten ett permanent straff. Samhällstjänsten är ett straff som inskränker friheten. Den som dömts till samhällstjänst måste, vid behov med hot om påföljder, begränsa sin fritid och den dömde måste under övervakning oavlönat arbeta det timantal som domstolen förordnat (20-200 timmar) vid den tjänstgöringsplats som anvisats. Kriminalvårdsföreningen ansvarar i dag för verkställigheten av påföljden.

Det nya straffets tillämplighet i det finska påföljdssystemet väckte dubier ännu i begynnelseskedet av strafflagens helhetsreform, som inleddes under 1970-talet. Straffet, vid vars användning gärningsmannens lämplighet för straffet betonas, anpassas inte friktionsfritt till ett påföljdssystem som framhäver den nyklassiska proportionalitetsprincipen. En del dubier hade samband med rädslan att påföljden antingen skulle användas i stället för tidigare böter och villkorligt fängelsestraff, såsom fallet varit i flera andra länder, eller alternativt förbli utan praktisk betydelse. Den specialpreventiva betoning som i viss mån anknyts till samhällstjänsten väckte dessutom kritiska tonfall i en situation, då påföljdssystemet till övriga delar reviderats i en nyklassisk anda med stark betoning av allmänprevention. Den nya påföljden har likväl utan större problem integrerats i det finska påföljdssystemet. Dess användningsområde har därtill blivit mer omfattande än man på förhand kunnat tänka sig. Samhällstjänsten har funnit sitt tillämpningsområde genom att inrikta sig på det ovillkorliga fängelsestraffet, dvs. det ursprungliga syftet har uppfyllts.

\section{Systemet i huvuddrag}

Vid tillämpningen och användningen av samhällstjänst kan man särskilja tre skeden: utredning om lämpligheten, dömandet och verkställigheten.

Påföljden är avsedd endast för sådana personer som är därtill lämpliga. Lämpligheten utreds medelst en särskild lämplighetsutredning. Efter att åklagaren beslutat väcka åtal för sådant brott för vilket samhällstjänst kan dömas, skall han av Kriminalvårdsföreningens distriktsbyrå inhämta en utredning om den misstänktes lämplighet för samhällstjänst. En utredning behöver emellertid inte inhämtas, "om det med hänsyn till arten och längden av det straff som kan förutses samt övriga omständigheter är uppenbart osannolikt att i stället för detta straff döms till samhällstjänst” (STF, 1259/1990, 2 §). Domstolen kan likväl på eget initiativ införskaffa en utredning. Den anklagade kan även framställa en 
begäran om utredning, men denne har inte någon absolut rätt till införskaffande av utredning. Kriminalvårdsföreningen kan också på begäran av den misstänkte göra nämnda utredning, om det finns vägande skäl.

Användningen av samhällstjänst skall vid domstolen prövas först i det skedet då man beslutat att utdöma ett ovillkorligt fängelsestraff. I lagen har således intagits ett förfarande i två faser. Domstolen väljer (a) först en straffart utan att ta i beaktande möjligheten att döma samhällstjänst och, om denna prövning resulterar i ett ovillkorligt fängelsestraff, skall domstolen (b) pröva möjligheten att utdöma samhällstjänst. Syftet med förfarandet är att säkerställa en faktisk användning av samhällstjänst som ett alternativ till ovillkorligt fängelse, inte som ett alternativ till ett lindrigare straff.

Det första villkoret vid dömande till samhällstjänst är att gärningsmannen döms till ovillkorligt fängelse och att detta straff inte överskrider åtta månader. För det andra förutsätts att svaranden ger sitt samtycke till samhällstjänst. En tredje förutsättning är att svaranden kan antas klara av samhällstjänsten. Svarandens möjligheter att klara av straffet övervägs av domstolen med stöd av Kriminalvårdsföreningens lämplighetsutredning. Lämpligheten avgörs i praktiken av Kriminalvårdsföreningens utlåtande. Ifall man avviker från utlåtandet, måste avvikelsen alltid motiveras (se HD 1996:9 och 1998:76).

Den fjärde förutsättningen har anknytning till gärningsmannens tidigare brottslighet. Trots att utgångspunkten är att fängelse förvandlas till samhällstjänst då de formella förutsättningarna för samhällstjänst uppfylls (dvs. att straffet är högst åtta månader och att gärningsmannen kan antas klara av straffet), är det även möjligt att döma ovillkorligt fängelse, om "ovillkorliga fängelsestraff, tidigare samhällstjänststraff eller andra vägande skäl skall anses utgöra hinder för att ett samhällstjänststraff döms ut" (STL $3 \S, 1055 / 1996)$. Domstolarnas praxis har varit relativt flexibel. Ett samhällstjänststraff har enligt högsta domstolens praxis varit möjligt även för en gärningsman som tidigare dömts till flera villkorliga och delvis ovillkorliga fängelsestraff, ifall det dock gått en längre tid sedan dessa brott begåtts (se HD 2000:11).

Domstolen måste alltid också fastställa antalet samhällstjänsttimmar. Samhällstjänstens längd är minst 20 och högst 200 timmar. Tjänstens längd bestäms i praktiken enligt det ursprungliga fängelsestraffet. Det härvid iakttagna förvandlingsförhållandet har inte fastställts i lagen, men det kan härledas ur de tilllämpliga latituderna. I lagens förarbeten intogs därtill en förvandlingstabell som styr lagskipningen. Enligt denna tabell motsvarar en fängelsedag en arbetstimme. I praktiken är detta förvandlingsförhållande inte så här förmånligt för den som avtjänar ett samhällstjänststraff, på grund av att en fånge försätts i villkorlig frihet efter att ha avtjänat antingen hälften eller två tredjedelar av strafftiden.

Förvandlingsförhållandet har kritiserats för att det inte motsvarar de faktiska skillnaderna i stränghet mellan fängelse och samhällstjänst (så i synnerhet enligt riksåklagare Matti Kuusimäki i flera olika sammanhang). Det är svårt att 
bedöma det exakta stränghetsförhållandet mellan påföljderna, då vi här saknar nödiga fasta och entydiga kriterier. Samhällspåföljderna ställer krav på den dömde som avviker från de traditionella straffen. Detta gör dem inte nödvändigtvis "mindre ingripande" än de övriga påföljderna, även om det är svårt att sinsemellan avväga det lidande en internering föranleder och de krav som samhällstjänsten ställer på den dömde. En viss betydelse vid bedömningen bör även tillmätas det faktum att verkställigheten av samhällstjänststraffet för en förstagångsförbrytare tar dubbelt längre tid än ett fängelsestraff. Vid ett samhällstjänststraff är man m.a.o. en längre tid "bunden under veckosluten" och "tvingad till nykterhet", vilket ofta är en krävande prestation av de personer som dömts till påföljden.

Vid bedömningen skall därtill även iakttas andra synpunkter där tyngdpunkten inte ligger vid en ren jämförelse av strängheten. Ifall en exakt stränghetsmotsvarighet skulle vara den enda grunden, skulle man inte alls ha behövt ta $\mathrm{i}$ bruk samhällstjänst. Den egentliga frågan lyder inte: "Motsvarar ett dygns fängelsevistelse $i$ en tänkt valsituation en arbetstimme?" utan frågan lyder: "Kan man som en helhet framlägga godtagbara grunder för ett förvandlingsförhållande mellan samhällstjänststraff och fängelsestraff, när vi tar $i$ beaktande påföljdernas inverkan på den dömde och samhället även $i$ vidare bemärkelse?" En viss tyngd i denna godtagbarhetsbedömning bör även tillmätas det faktum att samhällstjänsten som påföljd är mer konstruktiv och dessutom mindre skadlig ifråga om sin återfallsverkan än fängelsestraffet (se nedan). Ifall förvandlingsförhållandet skulle stramas till, skulle vi troligtvis riskera att komma i en situation där en stigande avbrytningsprocent skulle hota hela påföljdens framtid. Det skulle även vara möjligt att bli av med förvandlingsförhållandet genom att frigöra påföljdens användningskriterier från det ovillkorliga fängelsestraffet, vilket i sin tur skulle leda till en utökad användning av fängelsestraff.

Ett annat - och förmodligen mer allvarligt — problem är, att "lämplighet" som användningskriterium leder till likställighetsproblem när svarandens alkoholproblem bildar en riskfaktor för fullföljandet av samhällstjänsten. I en dylik situation löper svaranden en uppenbar risk att det vårdkrävande rusmedelsberoendet leder till bruket av anstaltsstraff. Lämpligheten som grund för användning av påföljden är således knuten till faran för social diskriminering (mer allmänt om dessa risker, se Kalmthouth 2000). Svaret borde emellertid inte vara att begränsa användningen av samhällstjänst, utan man borde skapa sådana arrangemang där lämpligheten inte längre skulle utgöra ett hinder för användning av samhällspåföljden. Man har till exempel strävat efter att minska denna fara genom att förena verkställigheten av påföljden med ett antal sociala stödåtgärder. Ett mer vittgående svar på denna kritik skulle emellertid vara att införa ett nytt vårdinriktat alternativ för dem som inte kan klara av samhällstjänst på grund av alkoholproblem (se nedan avsnitt VI). 


\section{Samhällstjänstens innehåll och verkställighet}

Kriminalvårdsföreningen svarar för verkställigheten av straffet. Föreningen skaffar och godkänner tjänstgöringsplatserna och övervakar utförandet av samhällstjänsten. Kriminalvårdsföreningen ingriper vid behov i brott mot tjänstgöringsvillkoren medelst muntliga och skriftliga anmärkningar, och domstolen kan avbryta samhällstjänsten och återförvandla straffet till fängelse.

Samhällstjänsten består av ett visst timantal regelbundet oavlönat arbete under tillsyn. Tjänsten avtjänas som 3-4 timmars arbetsperioder, vanligen två dagar i veckan. Avsikten är att tjänsten på detta sätt räknat skulle sträcka sig över en lika lång tidsperiod som avtjänandet av ett motsvarande fängelsestraff utan villkorlig frigivning. En viss del av samhällstjänststraffets timmar (högst fem) kan avtjänas genom att anlita tjänster inom missbrukarvården på ett sätt som Kriminalvårdsföreningen godkänner. Denna möjlighet begagnas i ca $10 \%$ av fallen.

Man strävar efter att samhällstjänstens arbetsuppgifter skall omfatta sådant allmännyttigt arbete som i annat fall helt skulle bli ogjort eller utföras som oavlönat arbete på frivillig basis. Tjänstgöringsplatsen kan arrangeras av ett offentligt samfund, ett offentligrättsligt samfund eller en offentligrättslig stiftelse. Typiska uppgifter har utgjorts t.ex. av hjälp $\mathrm{i}$ köket eller inom vårdarbetet $\mathrm{i}$ sociala serviceinrättningar, av större eller mindre reparationer samt iståndsättning av utomhusområden inom kommunerna och församlingarna samt av verksamhet i frivilliga biståndsorganisationers förråd och försäljningspunkter.

För utförande av samhällstjänsten fastställer Kriminalvårdsföreningen en tjänstgöringsplan med ett detaljerat tidsschema och övriga villkor för samhällstjänsten (STL 6 §). Då tjänstgöringsplanen görs upp skall den dömde även ges tillfälle att bli hörd, och planen skall i rimlig tid, innan tjänstgöringen börjar, delges den dömde på det sätt som gäller delgivning av stämning (STF 4 §).

Utförandet av samhällstjänsten övervakas mycket strängt. $\AA$ andra sidan är övervakningen koncentrerad till att trygga ett klanderfritt utförande av tjänsten. Övervakningen är emellertid inte förknippad med andra tillsyns- eller stödjande element. Övervakningen har m.a.o. i Finland inte något självständigt innehåll som en del av samhällstjänststraffet.

Påföljderna för brott mot villkoren och tjänstgöringsplanen har i lagen graderats enligt brottets beskaffenhet. Om den dömde handlar i strid med tjänstgöringsplanen eller andra villkor, skall Kriminalvårdsföreningen ge honom en muntlig eller skriftlig anmärkning (STL 7.2 §). Kriminalvårdsföreningen skall vid grövre brott mot villkoren för tjänsten göra en anmälan till allmän åklagare (STL 8 §). Detta gäller exempelvis sådana fall, där den dömde helt låter bli att infinna sig till tjänsten, avbryter utförandet av tjänsten eller på annat sätt grovt bryter mot villkoren för tjänsten (den dömde t.ex. i berusat tillstånd infinner sig på tjänstgöringsplatsen, vägrar att utföra tjänstgöringsuppgifter eller gör sig skyldig till brott på tjänstgöringsplatsen). Om åklagaren anser att samhälls- 
tjänsten skall förvandlas till fängelse, skall han yrka det vid den domstol som i första instans avgjort saken. Om domstolen anser att den dömde grovt brutit mot villkoren för tjänsten, skall domstolen förvandla den outförda delen av samhällstjänsten till ett ovillkorligt fängelsestraff. (STL 8.3 §). De redan utförda timmarna skall i sin helhet räknas den dömde tillgodo.

\section{Samhällstjänsten i praktiken}

Av Kriminalvårdsföreningen har under de senaste åren inbegärts ca 10000 lämplighetsutredningar. Utredningar har gjorts i $70 \%$ av de inbegärda fallen. Differensen förklaras delvis av att svaranden i vissa fall inte nås eller att han inte infinner sig till utredningen. Av utredningarna har $80 \%$ resulterat i ett positivt lämplighetsutlåtande.

Antalet årligen utdömda samhällstjänststraff steg snabbt till över tretusen. De ovillkorliga fängelsestraffens antal sjönk å sin sida i samma takt. Samhällstjänsten har således tydligt ersatt ovillkorliga fängelsestraff, vilket också var avsikten (Figur 1).

Figur 1. Antalet fängelse- och samhällstjänstdomar i Finland 1992-1999

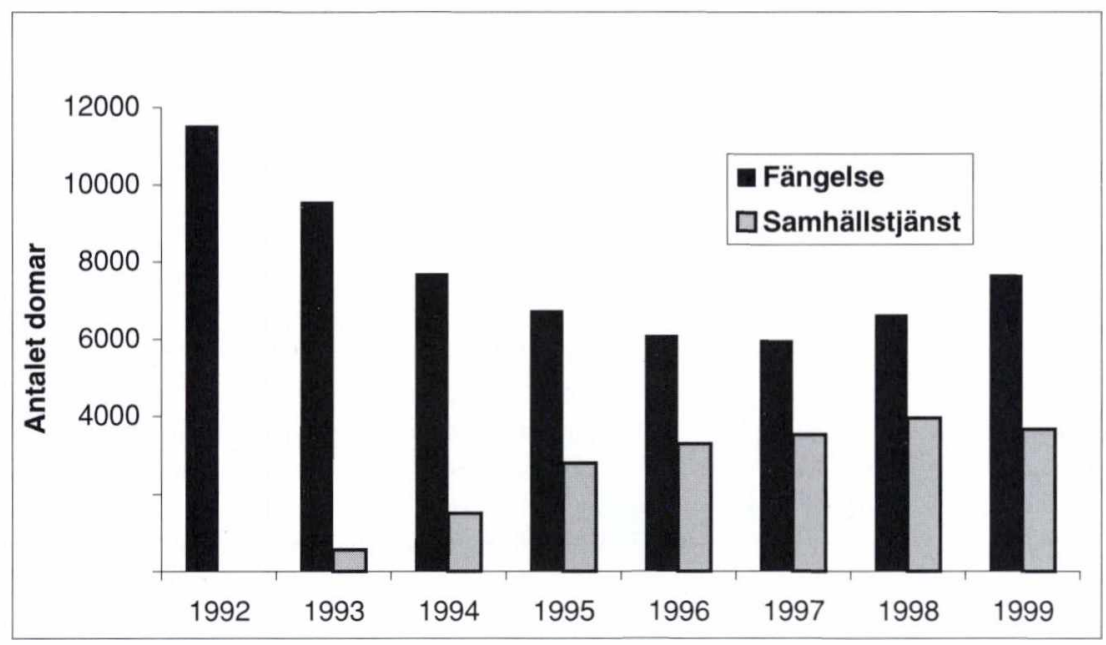

År 1999 utdömdes i domstolarna 3658 samhällstjänststraff, vilket utgjorde 38\% av de fängelsestraff som kunde förvandlas (max. 8 månader). Uppgifter om användningsgraden mellan 1995-1999 (\% av alla fängelsedomar max. 8 månader) ingår i tabell 4. 
Tabell 4. Till samhällstjänst dömda 1995-1999 (användningsgraden).

\begin{tabular}{|c|c|c|c|}
\hline & $\begin{array}{c}\text { Fängelse } \\
\text { max. 8 mån. } \\
\mathrm{N}\end{array}$ & $\begin{array}{c}\text { Samhälls- } \\
\text { tjänst } \\
\mathrm{N}\end{array}$ & $\begin{array}{c}\text { Användningsgraden } \\
\% \text { av fängelse } \\
\text { max. 8 mån. }\end{array}$ \\
\hline 1995 & 7536 & 2803 & 37,2 \\
\hline 1996 & 7340 & 3277 & 44,6 \\
\hline 1997 & 7621 & 3534 & 46,6 \\
\hline 1998 & 9132 & 3957 & 43,3 \\
\hline 1999 & 9594 & 3658 & 38,1 \\
\hline
\end{tabular}

Det nya straffets användningsgrad (= andel av fängelsestraff på högst 8 månader) steg under åren 1993-1997, men det verkar som om tillväxtten år 1998 skulle vara förbi. I bakgrunden ligger eventuellt en lagändring som trädde i kraft samma år. Genom denna ändring begränsade man användningen av samhällstjänst i återfallssituationer. Närmare uppgifter om samhällstjänst vid olika brottstyper ingår i tabell 5 .

Tabell 5. Samhällstjänstens andel vid olika brott 1993-1999.

\begin{tabular}{|l|c|c|c|}
\hline & $\begin{array}{c}\text { Antal samhälls- } \\
\text { tjänstdomar } \\
\text { N }\end{array}$ & $\begin{array}{c}\% \text {-av alla } \\
\text { samhälls- } \\
\text { tjänstdomar }\end{array}$ & $\begin{array}{c}\text { Användningsgrad } \\
\% \text {-av fängelse } \\
\text { max. 8 månader }\end{array}$ \\
\hline Rattfylleri & 2064 & 56,4 & 57,7 \\
\hline Stöld & 468 & 12,7 & 25,5 \\
\hline Misshandel & 302 & 8,2 & 38,4 \\
\hline Övrigt & 824 & 22,5 & 24,8 \\
\hline Alla brott & 3658 & 100 & 38,1 \\
\hline
\end{tabular}

Över hälften av samhällstjänstdomarna ges för rattfylleri. Andelen har dock sjunkit under åren 1993-1999 från 73\% till 56\%, vilket vittnar om att påföljdens tillämpningsområde utsträckt sig även till andra brott. Straffets användningsgrad (\%-av fängelse max. 8 månader) är alltjämt klart störst vid rattfylleribrott (58\% år 1999). Användningsgraden var 38\% vid misshandelsbrott och $26 \%$ vid stöldbrott.

År 2000 inleddes verkställigheten av 3315 samhällstjänststraff. Under året slutfördes 2770 straff. Av straffen måste 437 (13,2\%) avbrytas. Avbrottsprocenten (av dem som inletts samma år) har varierat mellan 11-15\%. 
Tabell 6. Verkställigheten 1995-1999.

\begin{tabular}{|c|c|c|c|c|c|}
\hline & Påbörjade & Genomförda & Avbrottsprocent & $\begin{array}{c}\text { Antal straff under } \\
\text { verkställighet 1 maj }\end{array}$ & $\begin{array}{c}\text { Antal verkställda } \\
\text { timmar/år }\end{array}$ \\
\hline 1995 & 2375 & 1720 & 11 & 696 & 169420 \\
\hline 1996 & 3041 & 2507 & 11,7 & 952 & 243583 \\
\hline 1997 & 3206 & 2620 & 13,3 & 1066 & 251862 \\
\hline 1998 & 3762 & 2933 & 13,6 & 1208 & 275788 \\
\hline 1999 & 3630 & 2979 & 15 & 1287 & 257107 \\
\hline 2000 & 3315 & 2770 & 13,2 & 1194 & 238129 \\
\hline
\end{tabular}

År 2000 verkställdes 240000 timmar samhällstjänst. Detta motsvarar 400-500 fångar av det dagliga fångantalet (om man utgår ifrån att man i brist på samhällstjänst verkligen skulle ha utdömt ett motsvarande ovillkorligt fängelsestraff). Den 1 maj 2000 var 1194 samhällstjänststraff under verkställighet.

Ett typiskt samhällstjänststraff har en omfattning på 70-90 timmar. Straffets omfattning har ett tämligen klart samband med att verkställigheten av samhällstjänststraffet avbryts. Av de avbrutna straffen hade den största andelen en omfattning på 91-130 timmar.

Enligt en utredning som fångvårdsavdelningen vid justitieministeriet genomfört kunde man beträffande återfall i brott förmärka en liten men systematisk skillnad mellan dem som dömts till samhällstjänst och dem som dömts till fängelsestraff. 55\% av dem som dömts till fängelse erhöll inom tre år en sådan ny dom som skall införas i brottsregistret (belastningsregistret). Av dem som dömts till samhällstjänst dömdes $52 \%$ på nytt inom samma tidsperiod. Andelen återfall i brott hade under fem år stigit till $67 \%$ beträffande dem som dömts till fängelse och till $61 \%$ i samhällstjänstgruppen. I utredningen strävade man efter att göra grupperna jämförbara (se närmare Muilu 1999).

\section{Ungdomsstraff}

\section{Ungdomsstraffrätten $i$ Finland}

Den i Finland förverkligade särskilda ordningen angående unga personer är internationellt sett anspråkslös. I princip tillämpas samma straffsystem på de unga som på de fullvuxna, om ock i en något lindrigare form. Att brott begåtts av en ung person mellan 15-17 år är en av de allmänna straffnedsättningsgrunderna (se SL 3:2). Man har i denna åldersgrupp även utvidgat förutsättningarna för åtals- och domseftergift (åtalsunderlåtelse och sanktionseftergift) samt villkorligt straff. Ett fängelsestraff som utdömts en ung person (vid gärningstidpunkten under 21 år) verkställs i allmänhet i en anstalt med från övriga anstalter tydligt avvikande förhållanden och en ung person friges tidigare (efter att $1 / 3$ avtjänats). Då en ung person döms till ett villkorligt straff, omfattar straffet i regel även övervakning, till åtskillnad från vad som gäller för övriga gärningsmannagrupper. 
I praktiken är den redan år 1940 stiftade lagen om unga förbrytare (262/1940) alltjämt den viktigaste "reformen" som gäller de unga. I och med denna lag tog man i bruk största delen av den nuvarande specialordning som gäller unga personer (åtals- och domseftergift, personundersökning beträffande unga personer, övervakning vid villkorligt straff samt det särskilda ungdomsfängelset). I Finland har man under de senaste årtiondena å andra sidan offentliggjort talrika planer på att utveckla påföljdssystemet för unga förbrytare. Först 1996 ledde detta arbete till lagstiftningsåtgärder. Härvid godkände riksdagen förslaget till det nya ungdomsstraffet (L om försöksverksamhet med ungdomsstraff (1058/1996), RP 109/1996). Frågan gällde en regionalt begränsad försöksverksamhet som ursprungligen planerades vara i kraft en treårsperiod (1.2.1997 31.12.1999). Försöksverksamheten förlängdes sedermera med två år till slutet av år 2001 (L 1092/1999, RP 35/1999).

Det nya straffet och behovet av detta motiverades rätt omfattande i förarbetena till ungdomsstraff. En del av motiven hade anknytning till en strävan att undgå användning av det villkorliga straffet i denna åldersgrupp. Återfall i brott är vanligt i de unga åldersgrupperna och det leder i det gradvis strängare systemet snabbt till den sista nivån på påföljdsstegen. Ett av ungdomsstraffets mål var att skapa ett ytterligare steg $i$ påföljdssystemet och på detta sätt fördröja ett förlopp som i sista hand leder till ovillkorligt fängelsestraff.

Man ställde även klara sociala mål för verkställigheten av påföljden. Man ville förena ungdomstjänsten med element, vars förenande drag utgörs av en strävan att främja den ungas sociala handlingsförmåga och ansvarskänsla. Genom påföljden försöker man "skapa kontakter mellan den unga personen och hans närmiljö och få honom att delta i olika aktiviteter avsedda för jämnåriga." Med hjälp av de program och kurser som ingår i ungdomstjänsten kan man också lära den dömda att använda samhällets tjänster. ”Syftet med övervakningen är också att stöda den unga $\mathrm{i}$ hans livssituation och i mån av möjlighet främja hans anpassning i samhället" (RP 109/1996).

Ungdomsstraffet är ett slags kompromiss mellan den nyklassiska och den sociala och rehabiliterande synvinkeln. I förarbetena poängteras även den nya påföljdens karaktär av straff: "I fråga om ungdomsstraffet är det ... alltid också fråga om ett straff $i$ den bemärkelsen, att påföljden innebär klander med anledning av ett brott. Att klarlägga betydelsen av brottet för gärningsmannen - dvs. att klargöra vad som är fel i gärningen och vilken inverkan den har t.ex. på offrets liv - skall utgöra en betydelsefull del av ungdomsstraffet" (RP 109/1996). Utöver de sociala målen poängterades även behovet av en konkretisering av påföljderna. Man hoppades att ungdomsstraffet skulle vara en mer konkret påföljd för de unga än det villkorliga straffet. Med reformen ville man dock inte helt ersätta det villkorliga straffet. Trots dessa olägenheter är, såsom i förarbetena konstateras, "ett villkorligt straff emellertid i många fall en fungerande påföljd. Den varning som ingår i det villkorliga straffet ser i största delen av fallen ut att fungera och fylla sin uppgift" (RP 109/1996). 
De första uppgifterna om användningen av påföljden vittnar om en tämligen trög start. Dessa uppgifter, samt den i offentligheten framförda kritiken mot det villkorliga straffet, ledde redan under försöksverksamheten till en justering av lagen om ungdomsstraff. Den år 1998 gjorda lagändringens syfte var att få ett nytt tillämpligt alternativ i s.k. brottskarriärfall redan före det första villkorliga straffet (RP 188/1998). I detta syfte gjorde man ett tillägg i lagen, genom vilket straffets användning kopplades till frågan hur gärningsmannen kommer att anpassa sig i samhället samt med risken att han begår nya brott. En av de ställda förutsättningarna för dömande till ungdomsstraff var att "dömande till ungdomsstraff skall anses motiverat för att förhindra återfall $i$ brott och för att främja gärningsmannens möjligheter att anpassa sig i samhället”.

\section{Dömande till ungdomsstraff}

En ung person som vid gärningstidpunkten fyllt 15 men inte 18 år kan dömas till ungdomsstraff. Förutsättningarna för användningen av straffet kan indelas i bedömningsgrunder som bestämmer brottet och dess klandervärdhet, samt sådana med stöd av vilka man kan bedöma gärningsmannens risk för återfall i brott och hans möjligheter att klara sig socialt samt bedöma hans behov av rehabilitering.

Den första förutsättningen för att tillämpa ungdomsstraff är att "böter med beaktande av hur allvarligt brottet är och omständigheterna vid brottet inte kan anses vara ett tillräckligt straff och vägande skäl inte kräver att ett ovillkorligt fängelsestraff döms ut" (USL $3.1 \S$ ). Genom bestämmelsen bestäms att ungdomsstraffets position på påföljdsstegen är på samma nivå som villkorligt fängelse (alltså mellan böter och ovillkorligt fängelse). Frågan huruvida brottet förutsätter en påföljd på denna nivå, avgörs i första hand utgående från hur allvarligt brottet är, dvs. med iakttagande av normala bedömningsgrunder vid bestämmandet av straff samt med iakttagande av grunderna för användning av villkorligt straff.

Det räcker emellertid inte med att bestämma att påföljden har en position på samma nivå som villkorligt fängelse. Man måste dessutom göra ett val mellan villkorligt fängelse och ungdomsstraff. Härvid skall man tillämpa det i lagen år 1998 intagna tillägget, enligt vilket påföljden skall tillämpas om "dömande till ungdomsstraff skall anses motiverat för att förhindra återfall i brott och för att främja gärningsmannens möjligheter att anpassa sig i samhället".

Allt i allt, unga personer som redan tidigare gjort sig skyldiga till brott utgör följaktligen den primära målgruppen för påföljden. Ungdomsstraff skall, enligt en allmän rekommendation $\mathrm{i}$ förarbetena, $\mathrm{i}$ regel användas först när återfall $\mathrm{i}$ brott sker trots att villkorligt straff utdömts. Lagens ordalydelse ställer å andra sidan inga hinder för att gärningsmannen döms "direkt" - utan mellansteget villkorligt straff - till ungdomsstraff. Ett av målen för lagändringen som gjordes år 1998 var uttryckligen att möjliggöra att döma även en sådan förbrytare till ung- 
domsstraff som inte ännu har dömts till villkorligt fängelse, men vars livssituation och risk för återfall i brott kräver mer konkreta åtgärder än villkorligt straff, t.ex. då en allvarlig brottslig karriär påbörjas eller pågår (RP 188/1998).

Efter att domstolen i sin prövning beslutat sig för ungdomsstraff, skall den dessutom besluta om längden av tjänsten och om övervakningen. Till ungdomsstraff döms i minst 10 och högst 60 timmar. Ungdomsstraff döms ut, i motsats till samhällstjänst, utan några mellaninstanser. Det är sålunda klart att antalet tjänstetimmar inte ställs i relation till fängelsestraff. I motiveringarna till regeringens proposition konstateras att "såsom i allmänhet vid straffmätning är utgångspunkten hur allvarligt brottet är och gärningsmannens skuld, utgående från vilka faktorer domstolen prövar antalet timmar ungdomstjänst som skall dömas ut" (RP 109/1996). Det sagda stämmer även till största delen in på fastställandet av tiden för övervakning.

\section{Ungdomsstraffets innehåll}

Ungdomsstraffet består av två delar: ungdomstjänst och övervakning.

Ungdomstjänsten innebär regelbundet oavlönat arbete under tillsyn samt uppgifter som utförs under handledning och som främjar den sociala handlingsförmågan (USL 2 §). Till ungdomstjänst döms i minst 10 och högst 60 timmar. Man strävar efter att utforma tjänstens innehåll så, att det ökar den ungas ansvarskänsla och befrämjar hans sociala kontakter. I förarbetena nämns som exempel på tjänsteuppgifter bl.a. olika kurser och studieprogram som lämpar sig för att kartlägga den ungas livssituation. Ett av syftena med försöksverksamheten är just att utveckla och testa modellprogram som genomförs i ungdomstjänsten.

Ungdomsstraffet är alltid förenat med övervakning. Till övervakning döms i minst fyra månader och högst ett år. Övervakningen har som uppgift att stöda och ge handledning åt den som dömts till ungdomsstraff. En del av övervakningen kan genomföras som gruppverksamhet.

Övervakarens huvudsakliga uppgift är att svara för att verkställighetsplanen iakttas, dvs. han skall övervaka att den unga som dömts iakttar verkställighetsplanen och de bestämmelser som fastställts med stöd av planen. Härtill hör även regelbundna träffar med den dömde på ett sätt som närmare bestämts i planen. Övervakaren skall dessutom hålla kontakt med platsen för ungdomstjänsten, för att försäkra sig om att ungdomstjänsten utförs i enlighet med bestämmelserna. Övervakaren kan även vid behov vara i kontakt med den ungas föräldrar.

Kriminalvårdsföreningen svarar för verkställigheten av ungdomsstraff. Föreningen utarbetar även verkställighetsplanen i samarbete med socialnämnden på den dömdes hemort och med övervakaren. Verkställigheten av ungdomsstraffet baserar sig i praktiken på arbetsprogram som utvecklats av kriminalvården och socialförvaltningen. Syftet med programmet vid övervakningsträffarna är bl.a. att öka den ungas förståelse för varför han begår brott, vad som är fel med att 
begå ett brott, vad brottet förorsakar offret och den unga själv, samt hur man i situationer som lockar till brott kan handla annorlunda. Också ungdomstjänstprogrammen har likartad betoning. Det egentliga arbetets andel i programmen har förblivit tämligen liten. I praktiken ser det därför ut som om skillnaden mellan ungdomstjänst och övervakning blivit rätt flytande. Enligt Kriminalvårdsföreningens direktiv skall övervakaren träffa den unga personen minst två gånger i veckan under de tre första övervakningsmånaderna och även härefter regelbundet i enlighet med den ungas personliga omständigheter.

Om den som dömts till ungdomsstraff handlar i strid med verkställighetsplanen eller med föreskrifter som meddelats med stöd av den, skall Kriminalvårdsföreningen ge honom en skriftlig anmärkning. Ifall fråga är om mer grova överträdelser (den dömde börjar t.ex. inte utföra ungdomstjänsten eller avbryter den), skall en skriftlig utredning göras till åklagaren. I de mest grova fallen skall åklagaren föra saken till domstol. Det ankommer på domstolen att besluta om påföljder för grova brott mot villkoren för ungdomsstraff. Domstolen kan förlänga övervakningstiden eller förvandla ungdomsstraffet till ett annat straff som motsvarar den del av ungdomsstraffet som inte har verkställts. Ett villkorligt fängelsestraff jämte tilläggsböter är ett straff som vanligen härvid kommer i fråga. Vid lagberedningen förhöll man sig mycket reserverat till tanken att ett ovillkorligt fängelsestraff skall utdömas i stället för ett ungdomsstraff. Då man utgår från att det redan vid utdömandet av ungdomsstraffet förutsätts att det inte finns vägande skäl som kräver att ett ovillkorligt fängelsestraff döms ut, ansåg man det vara motstridigt att straffet skulle förvandlas till ett ovillkorligt fängelsestraff enbart på grund av en överträdelse av villkoren. Faktum är emellertid att det trots allt i grovare fall blir aktuellt med ett ovillkorligt fängelsestraff.

\section{Ungdomsstraffet $i$ rättspraxis}

Fram till år 2000 har årligen drygt 50 ungdomsstraff utdömts. Detta har motsvarat ca en tiondel av antalet villkorliga fängelsestraff som personer inom försöksområdet dömts till i denna åldersgrupp. Användningen av straffet har emellertid märkbart ökat efter revideringen år 1998. De vanligaste brotten var olovligt brukande och stöldbrott, vilka är typiska för unga personer. I medeltal utdömdes 30 tjänstetimmar. Övervakningstidens medellängd var 8 månader (se närmare Rikollisuustilanne 1999).

Så gott som varje ung som dömts till ungdomsstraff hade tidigare dömts minst en gång till villkorligt fängelsestraff. I medeltal var de tidigare domarnas antal 2-3. De som dömts till ungdomsstraff hade dessutom ofta förordnats till stödåtgärder inom barnskyddet och de hade ofta placerats på anstalt. De har i regel missbruksproblem av något slag, en del har ett allvarligt narkotikaberoende eller ett fortsatt alkoholmissbruk. Ungefär en tredjedel lever i anstaltliknande förhållanden och en person av tio är utan stadigvarande bostad. De som dömts till ungdomsstraff har i många fall redan tidigare dömts till höga bötesstraff eller 
att erlägga skadestånd. Denna grupp har således ofta redan tidigare konfronterats med myndighetsverksamhet av olika slag.

Mer än var tredje som påbörjat ungdomstjänst avbryter utförandet av straffet, vilket är ett klart större antal än vid samhällstjänst. Av dessa har en anmärkningsvärt stor del även gjort sig skyldig till ett nytt eller flera nya brott. Bakom avbrytandet ligger i regel svåra drog- eller alkoholproblem och i vissa fall även svåra mentala problem. Det är uppenbart att ungdomsstraffet i dessa fall behöver ett avsevärt effektivare vårdsystem som stöd än det tillbudsståendee systemet för personer med narkotika-, alkohol- och mentala problem.

Man kunde redan på förhand anta att återfallsprocenten är hög för de personer som dömts till ungdomsstraff. Antagandet förstärks av ovannämnda uppgifter om bakgrunden och förhållandena i denna grupp. Av de 32 personer som år 1997 dömts till ungdomsstraff, hade 26 fram till juni 1998 dömts till ett straff (inkl. bötesstraff) efter det senaste ungdomsstraffet. Nio personer hade dömts såväl en som två gånger och tre personer hade dömts såväl tre som fyra gånger. Av två på nytt dömda hade den ena dömts fem och den andra sju gånger (se Statistikcentralen, Oikeus 1998:17, s. 8). Uppgifterna om återfall i brott vittnar - än en gång - om det straffrättsliga påföljdssystemets begränsade möjligheter, då det gäller försök att påverka problemungas beteende. Uppgifterna ger å andra sidan inte direkt anledning att anse att ungdomsstraffet helt har misslyckats. Uppgifterna ger samtidigt vid handen att detta straff tagits i bruk just beträffande den allra svåraste målgruppen, vilket också var den uttryckliga avsikten.

\section{Om medling}

\section{Medlingsförfarandet $i$ Finland}

En alternativ medlingsverksamhet av brott och tvister inleddes i Finland år 1983. Försöksverksamheten som inleddes i huvudstadsregionen (Vanda) bredde sig relativt snabbt till övriga delar av landet. Numera finns möjlighet till medlingsförfarande i de flesta av landets 452 kommuner.

Den i Finland ibruktagna medlingsmodellen betonar förfarandets alternativa karaktär. Medlingsförfarandet upplevs inte som en "egentlig" del av påföljdssystemet. Sambandet mellan påföljdssystemet och medlingsförfarandet kommer till synes närmast genom att medling nämns som en grund med stöd av vilken åtals- eller domseftergift kan komma ifråga. Medlingsförfarandets alternativa karaktär framgår även av att man inte har stiftat någon lag om förfarandet. Medlingsförfarandet har varit beroende av kommunernas egen aktivitet. Förfarandet grundar sig även till övriga delar på frivillighet. Medling är en möjlighet som erbjuds gärningsmannen och offret, den är ingen skyldighet. Medlingsförfarandet i sig består av frivilligt arbete. Medlarna är lekmän och de gör i praktiken oavlönat arbete. Medlarna får emellertid en av kommunen arrangerad kort skolning för uppgiften. 
Medlingsförfarandet har, oaktat sin inofficiella karaktär, i Finland uppnått synnerligen omfattande dimensioner. År 1997 inleddes i landet medlingsförfarande i ca 3600 brottmål. I målen hade 5200 personer gjort sig skyldiga till brott och 4200 personer var målsägande (se Mielityinen 1998).

\section{Medlingsprocessen}

Medlingsprocessen och den officiella straffprocessen verkar delvis parallellt. Målen kan komma till medlingsförfarande (och tillbaka till straffprocessen) från många olika håll.

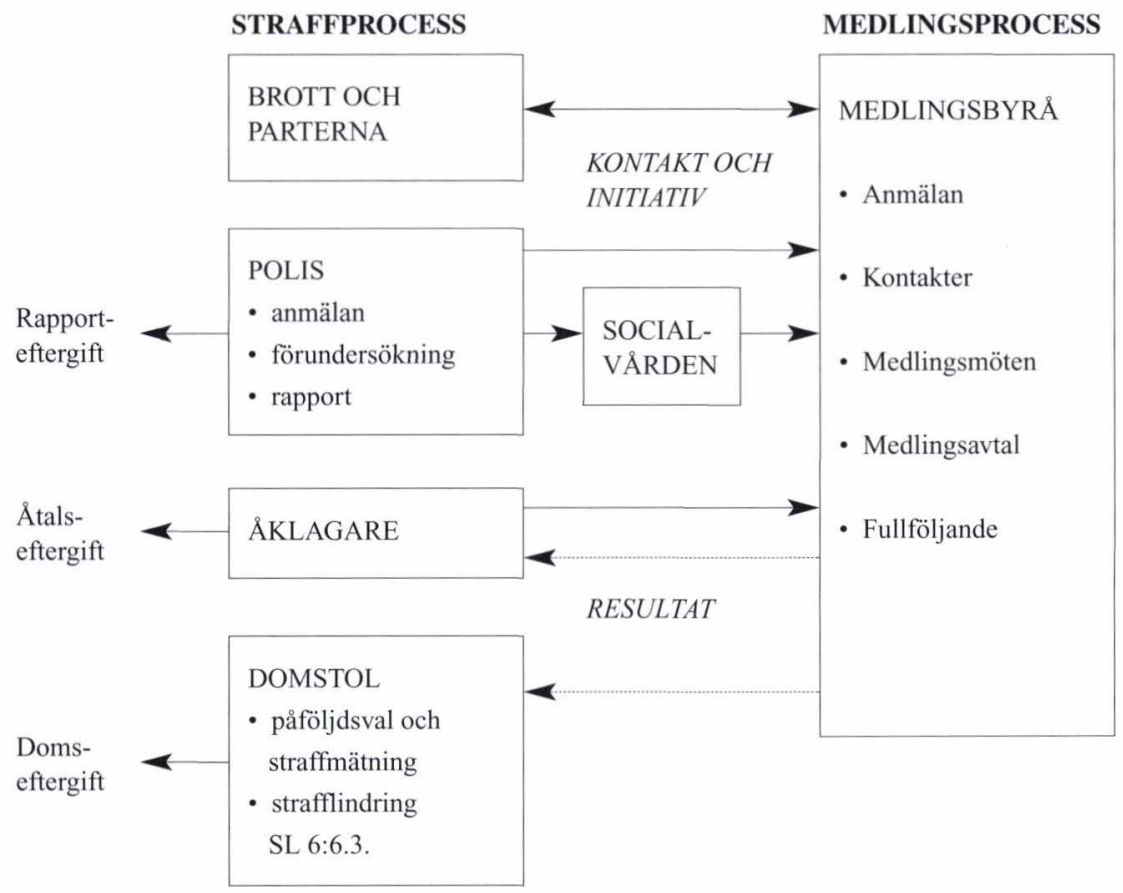

Medlingsförfarandet inleds då någon av målets parter tar kontakt med kommunens medlingsbyrå. Initiativet kommer antingen direkt från parterna, från polisen eller socialarbetarna, från Kriminalvårdsföreningen eller åklagaren. Medlingsbyrån kan även vara initiativtagare i saken. Medlingsförfarandet inleds i huvudsak på initiativ av åklagare (ca 45\%) eller polis (ca 40\%). Parterna var initiativtagare i 8\% av fallen (uppgifterna är från år 1997), medan socialmyndigheterna tagit initiativ i 5\% av fallen. Intitiativtagarna varierade i hög grad i de olika kommunerna. 
Efter att medlingsbyrån kontaktats, utreds parternas vilja att inleda ett medlingsförfarande. Ifall bägge parter är redo att inleda ett dylikt förfarande, arrangeras ett medlingssammanträde. I sammanträdet strävar man efter att kunna enas om det skedda (vem som gjorde vad, vilka skadorna var osv.), att kartlägga skadorna och att precisera de saker man kan medla. Ifall en medling inte nås i det första sammanträdet, arrangeras vid behov flera sammanträden. Medlaren fungerar som förmedlare. I den som direktiv för medlarna uppgjorda handboken poängteras att man inte på något sätt făr utöva påtryckning på parterna i syfte att ingå medling. Trots att medlarens uppgift är att främja ingåendet av medling, måste han även kunna hindra att oskäliga avtal ingås och han måste vid behov avbryta medlingsförfarandet, om förfarandet skulle hota någondera partens ställning (se Handbok för medlare i brott- och tvistemål 2000, s. 32 ff).

Av de mål där ett medlingsförfarande inletts, leder ca $60 \%$ till ett medlingsavtal. Parterna i målet bestämmer avtalets innehåll. Det är vanligen fråga om ett avtal som gäller skadestånd, och skadeståndet betalas i pengar, i vissa fall genom arbete. Avtalet kan även innebära endast en symbolisk ersättning, t.ex. framförande av ursäkt. Avtalet ingås skriftligt och man använder sig av avtalsmodeller som ingår i handboken. Avtalen innefattade år 1997 penningersättning i $60 \%$, arbete i $10 \%$ och annat (bl.a. ursäkt) i $30 \%$ av fallen. I ca $90 \%$ av fallen har avtalet hållit.

I medlingsförfarande behandlas närmast egendoms- och våldsbrott. Misshandel (38\%), skadegörelse (21\%) och stöld (17\%) är typbrott. Att misshandel som begåtts på privat område år 1995 blev ett brott som lyder under allmänt åtal, ledde till att andelen misshandelsbrott ökade. Samtidigt ökade andelen familjevåldsfall, vilket väckte livlig diskussion om familjevåldsfallens lämplighet för medlingsförfarande (se Takala - Mielityinen 2001).

Ungefär hälften av alla medlingsmål gäller gärningsmän under 18 år. Andelen gärningsmän under 15 år var 14\% år 1997. Så unga gärningsmän har inget straffrättsligt ansvar, men i medlingsförfarande kan ett avtal om ersättning av brottsskadorna ingås i vårdnadshavarnas närvaro. Andelen gärningsmän över 20 år var 36\%.

Medlingens betydelse i målets domstolsbehandling varierar beroende på om målet är ett målsägandebrott eller ett brott som lyder under allmänt åtal. Vid målsägandebrott kan straffprocessen helt undvikas med anledning av medling, om offret avstår från sina straff- och skadeståndsanspråk. Dryga hälften av medlingsmålen tillhör denna grupp. Vid brott som lyder under allmänt åtal nämns medlingsförfarandet (en medling som ingåtts mellan gärningsmannen och målsäganden) som en grund som talar för åtals- eller domseftergift. Åtalseftergift har varit klart vanligare i mål där medling ingåtts. Vid brott som lyder under allmänt åtal och medling ingåtts, meddelas åtalseftergift i över $60 \%$ av fallen, medan åtalseftergift i allmänhet meddelas (en aning beroende på mätningssättet) i under $10 \%$ av fallen. I mål som leder till domstolsbehandling, kan en med- 
ling leda till domseftergift eller enligt 6 kap. $3 \S 3$ punkten strafflagen till ett lindrigare straff.

\section{Diskussion}

Verkningarna och erfarenheterna av medlingsförfarandet har värderats i flera undersökningar som publicerats i Finland (Iivari 1991, Järvinen 1993, Takala 1998 och Mielityinen 1999). Värderingarna har allmänt haft en positiv ton. Man är tämligen överens om medlingsförfarandets förtjänster, även om medlingsförfarandets ofta olikriktade målsättningar i vissa fall poängterats olika i diskussionerna. Medlingsförfarandet är för målsäganden ofta ett effektivare medel (än den normala officialprocessen) att få skadorna ersatta. Fråga är inte enbart om pengar. En konfrontation med gärningsmannen kan även lindra den stress och rädsla som brottet föranlett. En öppen konfrontation med offret och med brottets konsekvenser kan för gärningsmannen i många hänseenden vara en erfarenhet som är lärorikare och som mera ökar den sociala ansvarskänslan än en rättegång. En utredning av konflikten, kommunikationen mellan de involverade och ingåendet av ett medlingsavtal är redan värden i sig. Medlingsförfarandet beräknas dessutom leda till stora ekonomiska inbesparingar. Man har beräknat att ett medlingsförfarande kostar under 1500 mark; endast en bråkdel av kostnaderna för en rättegång i motsvarande fall (se Iivari 2000).

Även polisernas och åklagarnas grundinställning har till största delen varit positiv. Visserligen kan det finnas en stor variation mellan olika myndigheters uppfattningar om vilka slags mål som är lämpliga för medlingsförfarandet och om medlingsförfarandets funktionsduglighet (Mielityinen 1999). Man har närmast oroat sig för hur parternas rättsskydd förverkligas. I vissa inlägg har även framförts en rädsla för att medlingsförfarandet i alltför stor grad kommer att utvidgas även till allvarliga brott (framför allt riksåklagaren Matti Kuusimäki). Det största problemet, då man ser på medlingsförfarandets framtid, torde dock vara att detta $i$ huvudsak mycket väl fungerande system inte täcker hela landet. Bristen på organiserade medlingstjänster i en stor del av landet har allmänt uppfattats som ett allvarligt likställighetsproblem. Emedan medlingsförfarandet även har en inverkan på behandlingen av brottmål i olika myndighetsinstanser, kan avvikande medlingsmöjligheter leda till en olik straffrättslig behandling $\mathrm{i}$ likartade fall. På basis av det ovannämnda har kraven på att skapa en fastare riksomfattande organisationsmodell och kraven på att lagstadga medlingsförfarandet ökat (se Iivari 2000). I dessa planer föreslås emellertid inte några ändringar i medlingsförfarandets övriga utgångspunkter eller i de principer som tillämpas i medlingsförfarandet.

\section{Värderingar och utvecklingslinjer}

Erfarenheterna av de nya samhällspåföljderna och medlingsförfarandet har till största delen varit positiva. Samhällstjänstens popularitet torde ha överraskat 
t.o.m. de myndigheter och sakkunniga som beredde reformen. Efter den första entusiasmen har användningsområdet för samhällstjänst dock inskränkts en aning. Detta har delvis varit en naturlig följd av att lagändringar gjorts och av att en del gärningsmän flera gånger hunnit bli dömda till denna påföljd, varvid man oundvikligen måste gå över till ovillkorligt fängelse. De senaste uppgifterna för det första kvartalet år 2001 ger vid handen att situationen emellertid numera stabiliserats.

Mer oroväckande än detta "naturliga bakslag" är att vissa höga tjänstemän riktat kritik mot samhällstjänsten och dess användningssätt. Denna reaktion kunde å andra sidan på många sätt förutses. Tecken på kriminalpolitikens allmänpolitisering och den punitiva populismens frammarsch har en längre tid varit synliga på andra håll i Europa, och det var endast en tidsfråga när denna diskussionstrend skulle nå Finland (se också Lappi-Seppälä 2000b). Utan att ta ställning till hur motiverad denna kritik är (om detta, se avsnitt III.2), hör det till realiteterna i praktiken, att samhällspåföljdernas fortsatta medvind till centrala delar beror på påföljdernas trovärdighet, och det faktum att ett straff uppfattas som ett tillräckligt strängt samhälleligt klander med anledning av en gärning. Man har vid verkställigheten av samhällstjänst strävat efter att försäkra sig om detta genom att strängt ingripa även vid mindre förseelser. De till detta straff dömda personernas egna utsagor bekräftar uppfattningen om ett krävande straff; i offentligheten framförda motsatta dubier till trots (se Linderborg 2001 s. $156 \mathrm{ff}$ ).

Erfarenheterna av de nya påföljdernas funktion har å andra sidan inte varit enbart positiva. Ungdomsstraffets grunddilemma är den frekventa återfallsbrottsligheten och den höga avbrytningsprocenten. Ett allvarligt likställighetsproblem vid tillämpningen av samhällstjänst är åter det faktum att de som på grund av rusmedelsproblem inte lämpar sig för påföljden måste avtjäna straffet i fängelse. Bägge missförhållandena anknyter på sätt eller annat till gärningsmannens rusmedelsproblem och därav förorsakad vård. Ett av de centrala uppgifterna då påföljdssystemet i fortsättningen utvecklas är att sammanjämka rusmedelsvården och straffsystemet. Justitieministeriet tillsatte i februari $2001 \mathrm{i}$ detta syfte en kommitté att bereda lagstiftningen gällande kontraktsvård. Påföljden skulle i likhet med samhällstjänst användas framför allt som ett alternativ till ovillkorligt fängelse. Kontraktsvård skulle i huvudsak riktas mot gärningsmän, som inte kan dömas till samhällstjänst på grund av rusmedelsproblem. Kommittén skall dessutom utreda om det finns ett behov att använda kontraktsvård som ett möjligt tilläggsstraff till villkorligt fängelse. Påföljdens gränser har avgränsats tämligen noggrant $\mathrm{i}$ uppdraget. Dömande till kontraktsvård skulle sålunda förutsätta den åtalades samtycke, och att han förbinder sig till den i domen fastställda vårdplanen och till övriga villkor. Vården kunde bestå av såväl vård $\mathrm{i}$ anstalt som vård $\mathrm{i}$ frihet. Emedan kontraktsvård skulle vara ett alternativ till ovillkorligt fängelse, skulle i påföljden alltid även ingå en vårdperiod $\mathrm{i}$ anstalt. 
Ett annat centralt uppgiftsområde i fortsättningen är utvecklandet av eftervården för fångarna. Även i detta fall måste vissa linjedragningar som gjordes redan på 1970-talet revideras. Avvecklandet av den stränga revirindelningen, som byggts upp mellan straffsystemet och den kommunala socialvården, är ett exempel i detta sammanhang (konkreta förslag har samlats i det nyligen publicerade kommittébetänkandet "Mot en brottsfri livskontroll", Kommittébetänkande 2001:2). Det är uppenbart att utvecklandet av en fungerande eftervård för fångar i Finland kommer att förutsätta en allt fastare sammanjämkning av påföljdssystemet och samhällets stödtjänster.

\section{LITTERATUR:}

Duff, R.A.: Punishment, Communication and Community. Oxford 2001.

Iivari, Juhani: Rikosten ja riitojen vaihtoehtosovittelu refleksiivisen oikeuden konseptiossa. Sosiaali- ja terveyshallituksen tutkimuksia 12/1991. Helsinki 1991.

Iivari, Juhani: Rikos- ja riita-asioiden sovittelun valtakunnallinen organisointi. Sosiaali- ja terveysministeriö. Työryhmämuistioita 2000:27.

Järvinen, Saija: Rikosten sovittelu Suomessa. Oikeuspoliittinen tutkimuslaitos. Tutkimusraportteja 175. Helsinki 1993..

Kalmthouth, Anton van: Community Sanctions and Measures in Europe: A Promising Challenge or a Disappointing Utopia. I verket Crime and Criminal Justice in Europe. Council of Europe 2000.

Komiteanmietintö 20001:2. Rikoksettomaan elämänhallintaan. Seuraamusjärjestelmän ja yhteiskunnan tukijärjestelmien yhteensovittamista selvittäneen toimikunnan mietintö. Helsinki 2001. ("Mot en brottsfri livskontroll. Betänkande av kommissionen för samordning av påföljdssystemet och de samhälleliga stödåtgärderna", Kommittébetänkande 2001:2.

Lahti, Raimo: Om den nordiska kriminalpolitikens utveckling. NTfK 3/2000 s.177-192.

Lappi-Seppälä, Tapio: The Fall of the Finnish Prison Population. Journal of Scandinavian Studies in Criminology and Crime Prevention 1/2000 s.27-40.

Lappi-Seppälä, Tapio: Kriminalpolitik-straffrättspolitik. NTfK 2/2000 s.113-135.

Linderborg, Henrik: Brott och straff. En undersökning av samhällstjänsten som straff. Åbo 2001.

Mielityinen, Ida: Rikos ja sovittelu. Valikoituminen, merkitys ja uusintarikollisuus. Oikeuspoliittinen tutkimuslaitos. Tutkimusraportteja 167. Helsinki 1999.

Muilu, Marja-Liisa: Yhdyskuntapalveluun tuomittujen uusintarikollisuus. Oikeusministeriön vankeinhoito-osaston julkaisuja 2/1999. Helsinki.

Rikollisuustilanne 1999. Oikeuspoliittinen tutkimuslaitos. Tutkimusraportteja 175. Helsinki 2000.

Rikosoikeuden yleisiä oppeja koskevat säännökset. Rikoslakiprojektin ehdotus. Oikeusministeriö. Lainvalmisteluosaston julkaisu 5/2000.

Sovittelijan opas. Rikos ja riita-asioiden sovittelijan opas. Suomen sovittelun tuki ry. Stakes. Oppaita 35. Helsinki 1999. (Handbok för medlare i brott- och tvistemål)

Takala, Jukka-Pekka: Moraalitunteet rikosten sovittelussa. Oikeuspoliittinen tutkimuslaitos. Tutkimusraportteja 151. Helsinki 1998.

Takala, Jukka-Pekka \& Mielityinen, Ida: Rikosten sovittelu ja parisuhdeväkivalta: Sovinnon aika?

I verket Sovittelu ja muut vaihtoehtoiset konfliktinratkaisumenetelmät (toim. Soile Pohjonen). Helsinki 2001.

Tilastokeskus: Oikeus 1998:17.

Vogt-Airaksinen, Tiina: Probation and Probation Services in Finland. I verket Probation and Probation Services. A European Perspective (red. Anton M. van Kalmthout \& Jack T.M. Derks). Nijmegen 2000. 
Adress: Rättspolitiska forskningsinstitutet

PB 1200

FIN-00 101 Helsingfors

E-post: tapio.lappi-seppala@om.vn.fi 